\title{
転位と不純物原子の相互作用に おける新たな進展
}

\section{1. は じめに}

材料開発の進展は休むことを知らない.5000年余の人類 の材料文明の歷史は多くの経験や試行錯誤の積み重ねであの た(1). 材料の様々の性質のなかで金属, 半導体, 絶縁体, あ らゆる固体材料に共通して強度の問題は常に少なからず重要 である(2). しかしながら, 結晶材料に限ってみても強度のメ カニズムがミクロな立場から理解されるようになったのは法 んの60年汪ど前のことである(3)-(5). 量子力学の発見よりも 「転位」の概念の発見が達かったことはちょっとした驚きで ある†。ちょうど50年前, Cottrell は刃状転位の応力場と不 純物原子雨の相互作用の機構を提案した ${ }^{(6)}$. これがミクロな レベルで合金強度を定量的に議論した最初である. その後, 転位論は FCC 金属, イオン結晶, BCC 金属そして金属間化 合物, 半導体, $\mathrm{HCP}$ 金属といらょうにあらゆる材料を対象 に発展してきた(7)-(12)．BCC 金属の研究は FCC 金属より後 発であったにもかかわらず, イントリンジックな抵抗障害で ある Peierls ポテンシャルの問題, エキストリンジックな抵 抗である不純物原子の場合ともかなり正確にミクロな機構が 理解されてきた (13)(14)．それに比べて先発の FCC 金属では, 本質的な所でいまだよく理解できてない問題がいくつかあ る(15)-(17). 転位論が説明のための学問で予測のためには使

\section{小 杉 俊 男*}

えないといった批判がささやかれたのも FCC 金属で十分な 成功が得られなかったせいかもしれない。しかし転位論が役 にたたないといらのは誤解であって，BCC 金属での成功や 最近の半導体に执ける原子レベルでの精密な議論はとのよう な誤解を払拭してくれると思う(13)。それでは，なぜ FCC 金 属が難しいのか?

FCC 金属では Peierls ポテンシャルが非常に小さい(11). そのため転位の運動は低温至るまで不純物原子との相互作 用に支配されているといってよい。すなわち BCC 金属で は，らせん転位が主たる障害である Peierls ポテンシャルを 乗り越光て, 次にキンクがポテンシャルに沿って1次元的 に移動するときに不純物原子が障害となるが(14)，FCC 金属 では転位は 2 次元的に自由に動きうるので不純物原子の 2 次元的分布をどのようにとり扱らのかが大きな問題とな $る^{(15)}$. 特に, 希薄合金系に捜いて不純物原子が固溶原子と して転位と相互作用して合金強度を高める機構についてはい まだ定性的な見解も定まっていない(16)(17)．この「固溶体強 度」の理解は, 3 つの階層の問題に㷌着される ${ }^{(15)}$. (1) 1 個 の不純物原子と転位の間の相互作用の要因を明らかにする (「基本的相互作用」の問題) こと (18)，(2) 1 本の転位線が応力 下，有限温度で運動する状況を理解すること(19)-(24), そし て(3)多くの転位が運動する場合, 移動過程と増殖過程のどち らが塑性現象を律速するか理解すること (16)(25). 何が固溶体

\footnotetext{
*広島大学講師 ; 理学部物理科学科(年739-8526 東広島市鏡山1-3-1)

A New Progress on Dislocation-Impurity Atom Interactions; Toshio Kosugi(Department of Physics, Faculty of Science, Hiroshima University, Higashi-Hiroshima)

Keywords: internal friction, amplitude dependence, dislocation, impurity atom elementary interactions, solid solution strengthening, low temperature

†量子力学の発見をPlanck の量子仮説(1900年)の年と察ることもできるが, 古典力学に代わる確固とした体系として建設された年 (Heisenberg の行列力学(1925年)打よび Schrodinger の波動力学(1926年)発見の年)と考えても，塑性をになう「転位」の概念の発見 (1934年)より10年も早い.

1998年12月17日受理
} 
強度の問題に执いてが解決されていないか？ 1 つは 1 個の 原子との相互作用すなわち「基本的相互作用」について正確 な実験データがなかったことと，定量的に正確な理論的予測 が立っていないこと．そのため降伏応力などの実際の強度を 定量的に強度の理論と比較することができなかった．次に， 1 本の転位運動の要素過程が明らかになっていなかったこ そ.これは基本的相互作用の大きさが明確に決まっていなか ったことと少なからず関係している。そして一番よく分から ないのは塑性現象に打ける転位構造の進展過程の律速機構で ある. 律速しているのは移動過程(摩擦機構)なのかそれとも 増殖過程 (固着機構)なのか?

我々がここでまず明らかにしようとするのは，そのような 強度の基本的相互作用と考光られる孤立した 1 個の溶質原 子と転位の相互作用である ${ }^{(15)(18)}$. そのための実験手段とし て振幅依存性内部摩擦(ADIF)を利用した ${ }^{(26)}$. 塑性变形実験 のようなマクロな変形(歪0.1\%以上)では転位の運動は長距 離汇渡り，転位間相互作用が無視できない，そのため溶質原 子の効果を調べるのに最低 $0.1 \%$ 以上濃度が必要である.

一方 ADIF では $1 \mathrm{ppm}$ の濃度でも溶質原子の効果を測定で きる程感度がよい，さらに非破壊の測定なので 1 本の結晶 試料によって様々の系統的測定が可能である.

次章ではまず，「基本的相互作用」を測定するための条件 について述べる， 3 章では我々の実験の原理的な部分を紹介 乙, $\mathrm{Al}$ 希薄合金について低温に批ける振幅依存性内部摩擦 (ADIF)を測定した結果と特徵について述べる.さらにその 結果を転位の離脱モデル (Granato-Lücke モデル)に基づいて 解析する. 特に ADIF の温度依存性に注目して解析を行っ た. との結果 1 個の溶質原子と転位の相互作用に関する詳 細な情報が得られた. 特に, 提案した相互作用ポテンシャル 飞基づき温度依存性を説明できた。 4 章では応用として, 前 半では個及の溶質原子について得られた相互作用ェネルギー をいまをでの理論と比較し相互作用の原因を考光た. 後半 は, 塑性に括ける固溶体強度現象のメカニズムについて考兄 た。

\section{2. 基本的相互作用を測定するには}

1 個の原子との相互作用が原理的に測定可能かどらか簡単 な推定を前もって示すことは重要であろう ${ }^{(27)}$. 図 1 亿転位 のセグメントが不純物原子によってピン止めされている様子 を示す. 応力 $\sigma$ を加えると転位線がループ状に張り出すが, この転位ループのらち一番弱いところから転位の離脱が始ま る. それは最大 2 重ループ $l_{1}+l_{2}$ の中心のピン止め点であ る. ピン止め点に働く力 $F$ は $F=\left(l_{1}+l_{2}\right) \sigma b / 2$ と与兄られる から, 最大ピン止め力を $F_{\mathrm{m}}$ とすると離脱応力 $\sigma_{\mathrm{M}}$ は $F_{\mathrm{m}}$ $=\left(l_{1}+l_{2}\right) \sigma_{\mathrm{M}} b / 2$ から求められる.ここで $b$ は Burgers ベク トルの大きさである. 有限温度では, $\sigma_{\mathrm{M}}$ 上り小さい応力で も熱の助けを借りて離脱でさる。その温度に対する依存性は

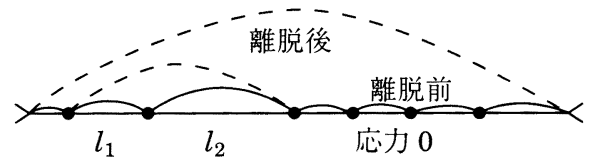

図 1 応力下の転位セグメント。両端は転位のネット ワークの分岐点になっている.

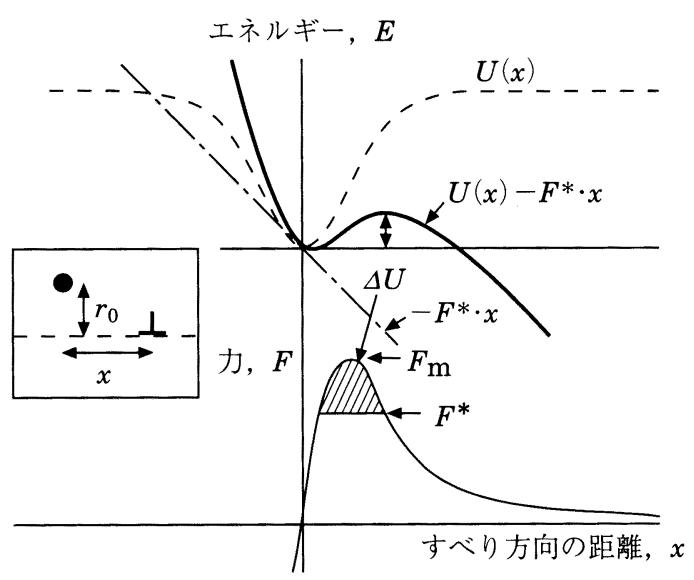

図 2 相互作用ポテンシャルと力. $x$ はすべり方向のピ ン止め原子と転位の距離. 外力 $F^{*}$ を与えたとき の実効ポテンシャル $U(x)-F^{*} \cdot x$ も示してある.

3 章で述べるように転位とピン止め原子の相互作用ポテンシ ャル(図 2)を仮定すれば計算できる。しかしここで注意しな ければならないのは 2 重ループの長さが十分長い場合には 常に離脱が可能だが，短いループでは離脱後の平衡状態が低 応力では不安定もしくは存在しない場合がある点である(28). この場合, もはや離脱の要素過程は最大 2 重ループからの 離脱でなく、 3 重ループとか 4 重ループからの同時離脱を考 える必要がある(29).ここでいう長さは相対的なもので, 例 えば, 長いループでも高温, 低応力下では 2 重ループから の離脱は不可能になる.

具体的に, どの程度の 2 重ループがクリティカルな長さ か推定してみる、いまモデルポテンシャルとしてよく引用さ れる Cottrell ポテンシャルを仮定する.

$$
E_{\mathrm{I}}(x)=U(x)=U_{0} \frac{\left(x / r_{0}\right)^{2}}{1+\left(x / r_{0}\right)^{2}} \quad \text { (Cottrell) }
$$

ここで $U_{0}$ は相互作用エネルギーの大きさ， $r_{0}$ はピン止め原 子とすべり面の距離, $x$ はすべり方向の転位中心とピン止め 原子の距離である. 次に, 転位の線エネルギーの変化は,

$$
E_{\mathrm{II}}(x)=\frac{\mu b^{2} x^{2}}{\left(l_{1}+l_{2}\right)}
$$

で与えられる。ここで， $\mu$ はずれ弾性率である。また，応力 のがする仕事が

$$
E_{\mathbb{I I}}(x)=-\frac{\sigma b}{2}\left(l_{1}+l_{2}\right) x
$$




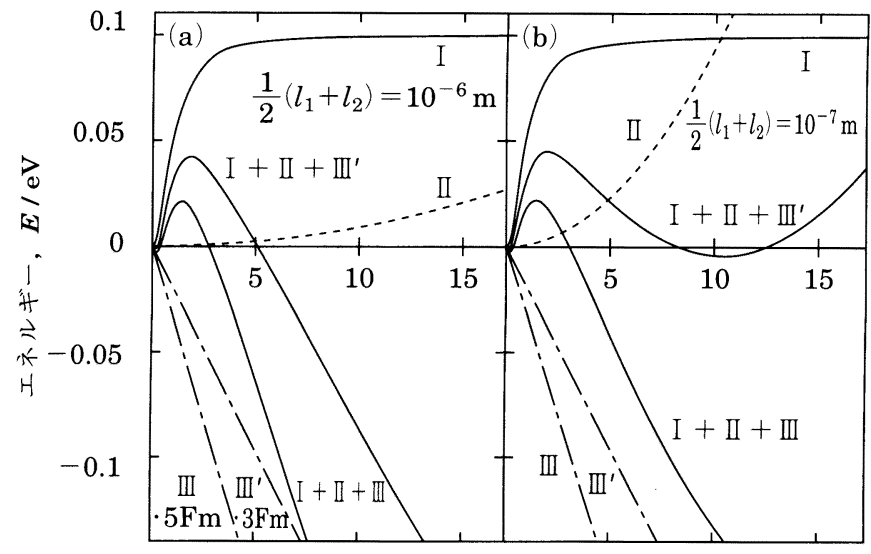

すべり方向の距離, $x / r_{0}$

図 3 ピソ止めされた転位の 2 重ループのエネルギー 変化. (a) 長いループ, (b) 短いループ.

となり，この 3 つのェネルギーを合わせたものが応力 $\sigma$ 下 での実効ポテンシャルになる(28).

いま, $\mathrm{Al}$ 結晶の場合を想定し $\left(\mu=2.7 \times 10^{10} \mathrm{~Pa}, r_{0}=1.17\right.$ $\left.\times 10^{-10} \mathrm{~m}\right)$, 典型的な $U_{0}$ の值 $0.1 \mathrm{eV}$ に対して実効ポテン シャルを示したのが図 3 である.ここでは最大 2 重ループ の長さ $l_{1}+l_{2} を\left(l_{1}+l_{2}\right) / 2=10^{-6} \mathrm{~m}$ と $10^{-7} \mathrm{~m}$ の場合につい て示した.な打応力レベルは最大結合力 $F_{\mathrm{m}}$ の $50 \%$ 扎よび 30 $\%$ の場合を示した. $\left(l_{1}+l_{2}\right) / 2=10^{-6} \mathrm{~m}$ の場合は線張力の影 響は実効ポテンシャルにほとんど効かない，ところが，（ $l_{1}$ $\left.+l_{2}\right) / 2=10^{-7} \mathrm{~m}$ の場合, $0.5 F_{\mathrm{m}}$ からすでに実効ポテンシャ ル障壁の高さに線張力の影響がわずかながら現われて特り高 くしている.さらに $0.3 F_{\mathrm{m}}$ に至ると, 離脱状態のエネルギ 一極小がピン止め状態の極小と注ぼ同じレベルになる，これ は離脱状態が安定でないことを意味する. 従って, 2 重ルー プからの離脱が不可能になり，3 重，4 重といったより長い 多重ループの同時離脱の過程に遷移する ${ }^{(29)}$.

$\left(l_{1}+l_{2}\right) / 2=10^{-7} \mathrm{~m}$ はピン止め濃度でいうと $3 \times 10^{-4}$ に 相当する. 転位線上の不純物濃度が相互作用のため普通, バ ルク中より高いことを考えると, 平均濃度が $0.01 \%$ 以上の不 純物濃度では線張力の影響が効いてくる. そのため, より単 純な 2 重ループからの離脱のみで現象を取り扱うには, バ ルクの不純物濃度が $0.01 \%$ 以下の試料の測定が必要になる. 従って塑性変形実験から基本的相互作用を測定することは不 可能である. ADIF では十分この条件をクリアーするだけの 感度がある。また測定が非破壊的なので 1 本の試料から詳 細な研究ができる.

\section{3. 振幅依存性内部摩擦(ADIF)の低温測定}

\section{（1） ADIF の測定結果の特待}

内部摩擦の測定には $\mathrm{Al}$ 結晶を用いた. $\mathrm{Al}$ の特徵は $\mathrm{FCC}$ 金属なので Peierls ポテンシャルが非常に小さく, 転位の運

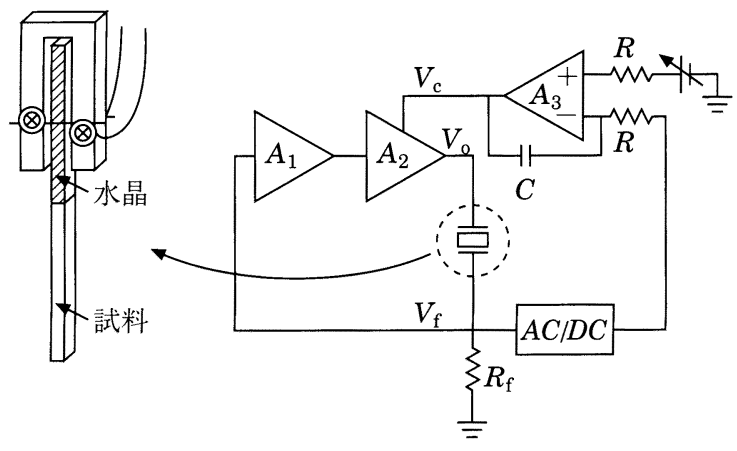

図 4 複合振動子法. 我々の方法では, フィードバッ ク回路によって振動子が定常振動を維持するよ らにしている.

動は不純物原子との相互作用で決定される.ささらに弾性異方 性が小さいので多結晶でもそれなりに正確な測定ができる. 公称 $5 \mathrm{~N}$ の $\mathrm{Al}$ を母金属として用いた．電気抵抗測定による と残留不純物量が $4 \mathrm{ppm}$ 程度であるので, 導入する溶質原 子量を20〜100 ppm の範囲にした。 また, 単結晶を用いる 湾らがより特定したデータを得られるので, 歪焼鈍法により 単結晶化を図った。最初に紹介するデータは, Al-100 ppm $\mathrm{Zn}, \mathrm{Al}-50 \mathrm{ppm} \mathrm{Ag}, \mathrm{Al}-25 \mathrm{ppm} \mathrm{Mg}, \mathrm{Al}-20 \mathrm{ppm} \mathrm{Cu}$ 単結晶に 関してである(27).これらの試料は内部摩擦測定前に $770 \mathrm{~K}$

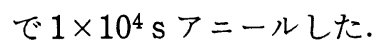

内部摩擦は, 水晶駆動・受信子を用いた複合振動子法を用 いた ${ }^{(30)}$ (図 4). この方法の特長は雨振幅 $10^{-8} \sim 10^{-4}$, 内部 摩擦 $10^{-6}$ 10-2 の広い範囲で正確な測定がでさることであ る. また長さが約 $10 \mathrm{~cm}$ とコンパクトなので低温での測定 が容易にできる. 但し, 振動数を広い範囲で変えられないこ と(普通は基本振動数のみ), クライオスタットに試料を直接 固定できないので熱接触に $\mathrm{He}$ ガスを用いる必要がある. し かしながら, 本目的のような振幅依存性を精密に測定するに

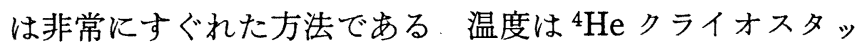
トを用いて最低温度 $1.6 \mathrm{~K}$ まで測定した。

図 5 に $4.2 \mathrm{~K}$ での内部摩擦の振幅依存を示す. 内部摩擦の 大きさはここでは対数減衰率 $\Delta\left(=\pi Q^{-1}\right)$ を用いて表わ す(31). 横軸は応力振幅をヤング率 $E$ で割ったもので歪振幅 に相当する. 試料間のヤング率の違いは $8 \%$ 以内であり, 応 力振幅について比較していると考えてもよい. Schmid 因子 $\Omega$ は $100 \mathrm{ppm} \mathrm{Zn,} 50$ ppm Ag, 25 ppm Mg, 20 ppm Cuにつ いてそれぞれ，0.445, 0.433, 0.471, 0.322であり $\mathrm{Al}-\mathrm{Cu}$ 以外 はほぼ等しい。アニールした $\mathrm{A} 1$ では低振幅領域の振幅に依 存しない内部摩擦 $\Delta_{\mathrm{I}}$ は音波と伝導電子の相互作用による background として説明できる(30)(32). 従って, 全内部摩擦 $\Delta$ は転位の運動に基づく振幅依存性内部摩擦 $(\mathrm{ADIF}) \Delta_{\mathrm{H}}$ と それとは独立の $\Delta_{\mathrm{I}}$ の和 $\Delta=\Delta_{\mathrm{H}}+\Delta_{\mathrm{I}}$ と表わせる。いま溶質 原子と転位との相互作用の強さの目安として振幅依存が現わ れる歪振幅値 $\varepsilon_{\mathrm{c}}$ に注目する. 1 原子当りの相互作用が等し 


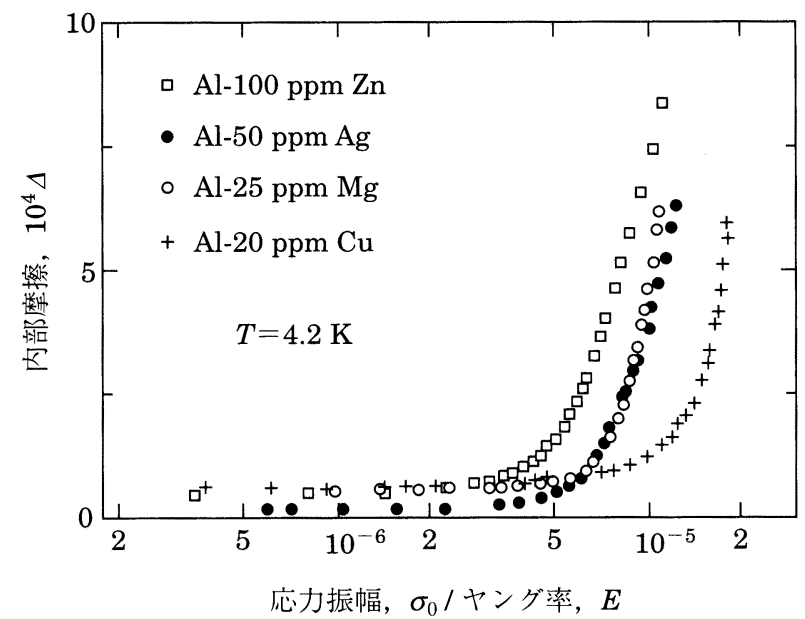

図 $54.2 \mathrm{~K}$ に抢ける内部摩擦の応力振幅依存.

い場合, 有効応力値 $\sigma_{\mathrm{c}}\left(=\Omega E \varepsilon_{\mathrm{c}}\right)$ は濃度が高い注ど高振幅側 に現われるはずだが，ここでは濃度の低い溶質原子ほど高振 幅側になっているので $\mathrm{Cu}, \mathrm{Mg}, \mathrm{Ag}, \mathrm{Zn}$ の順で相互作用が大 きいことが推測できる.

次に $\Delta_{\mathrm{H}}$ の温度依存について調べた，有限温度では熱活性 過程の助けによって絶対零度で必要な離脱応力ょり小さい応 力で転位は溶質原子のピン止めから離脱できる. 離脱応力の 温度依存から相互作用の大きさが測定できる. 図6亿一定レ ベルの $\Delta_{\mathrm{H}}$ の値を維持するのに必要な外部応力振幅 $\sigma_{0}$ の温 度依存性を示した，但し，迸軸は絶対零度への外挿値 $\sigma_{0}(T$

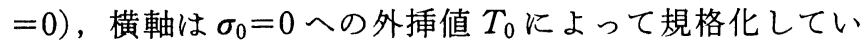
る. この図から直ちに次のようなことが分かる.すなわち, 溶質原子種によらず共通して,

(1) $\sigma_{0} / \sigma_{0}(T=0) \geqq 0.65$ の領域で $\sigma_{0}$ は $T^{2 / 3}$ に対して直線 的温度变化する $\left(T^{2 / 3}\right.$ 則).

(2) $\sigma_{0} / \sigma_{0}(T=0) \leqq 0.65$ の領域では $\sigma_{0}$ は $T^{2 / 3}$ 則より上側 にずれる.

$\sigma_{0}(T=0)$ 拉よび $T_{0}$ はこの $T^{2 / 3}$ 則に従ら領域からの直線外 挿值である. $T^{2 / 3}$ 則の領域は $\mathrm{Cu}, \mathrm{Pb}$ 結晶などでも観測され ている(33)(34)． $T_{0}$ は相互作用の大きさに比例するパラメー ターであるから溶質原子によって相互作用の大きさが異なる ことが分かる，それにもかかわらず，この共通の温度依存性 の出現は相互作用ポテンシャルを反映したものであることを 強く示唆する.すなわち 1 個の溶質原子と転位との相互作 用を反映した測定が ADIF によって可能であることが初め て示された。

\section{（2）離脱モデル(Granato-Lücke モデル)に基づく熱活性 解析}

転位がピン止め原子から離脱するために生じる ADIF を 転位弦モデルに基づき定量的な表現を与えたのが GranatoLückeによる離脱モデルなので要点を紹介する(26)(35)(36).

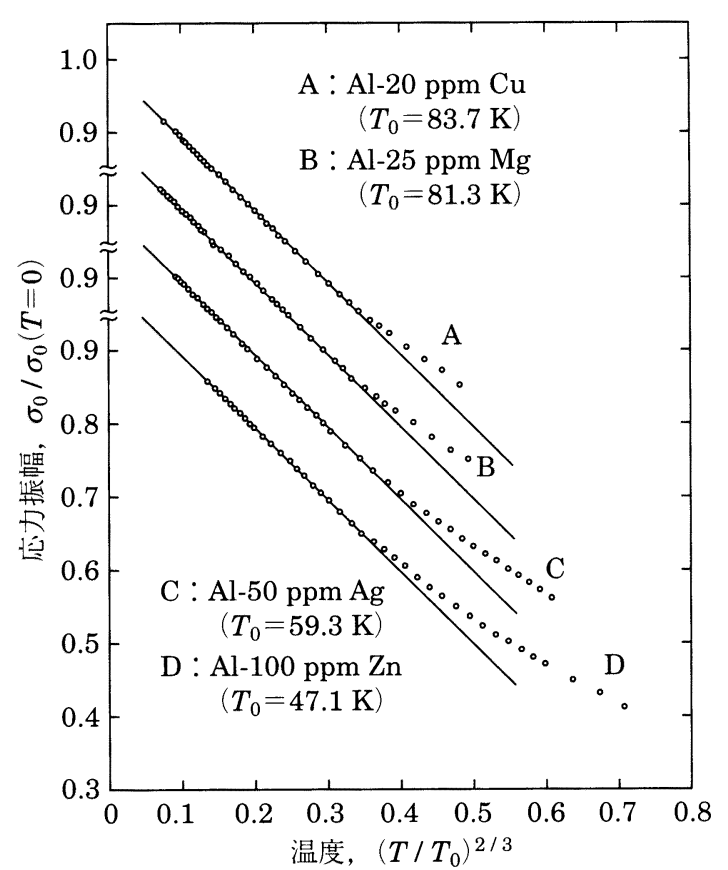

図 6 一定量の $\Delta_{\mathrm{H}}$ を維持するための応力振幅 $\sigma_{0}$ の温 度依存性.

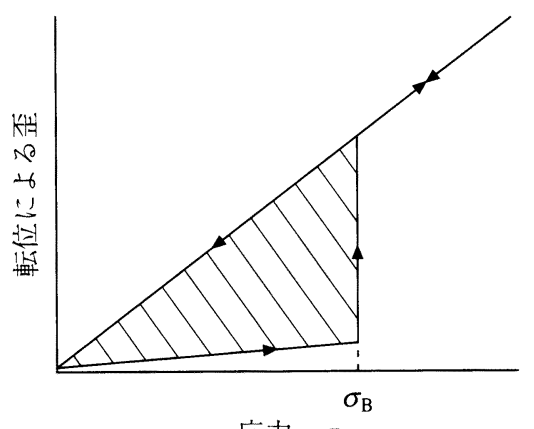

応力, $\sigma$

図 7 離脱による転位のヒステレシス.

図1飞执いて, ずれ応力を加兄ると, 転位は次第に張り出 乙, 離脱応力 $\sigma_{\mathrm{B}}$ 洼達すると, 最大 2 重ループの中心ピン止 め点から離脱を開始し, セグメント全体に渡って張り出す。 その後応力を下げていくと転位は離脱したまま戻ってきて， 応力が 0 になったところで再びピン止めされる. 従って, 図7のようにヒステレシスループが生じる.もし $\sigma_{\mathrm{B}}$ より大 きな振幅を持つ振動応力 $\sigma=\sigma_{0} \sin \omega t$ を与兄れば, 内部摩 擦が生じることになる。 $\omega$ は角振動数である. 最大 2 重儿 ープの長さが各転位セグメント間で等しいとき，ADIFによ る対数減衰率 $\Delta_{\mathrm{H}}$ は

$$
\Delta_{\mathrm{H}}=\Delta_{\mathrm{m}} \frac{\sigma_{\mathrm{B}}^{2}}{\sigma_{0}^{2}}
$$

で与兄られる。ここで $\Delta_{\mathrm{m}}$ は $\Delta_{\mathrm{m}}=\Lambda L_{\mathrm{N}}^{2} / 6$ で与えられる倸数 


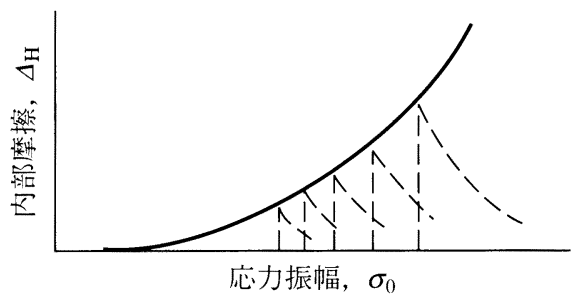

図 8 内部摩擦の振幅依存性の概念図. 破線は $\sigma_{\mathrm{B}}$ の分 布がない場合．実線は分布による重ね合せを考 慮した場合.

で $\Lambda, L_{\mathrm{N}}$ はそれぞれ転位密度，セグメントの長さである。 実際には, 最大 2 重ループの長さに分布があるので $\Delta_{\mathrm{H}}$ は

$$
\Delta_{\mathrm{H}}=\frac{\Delta_{\mathrm{m}}}{\sigma_{0}^{2}} \int_{1 / 2 \text { cycle }} \sigma_{\mathrm{B}}^{2} \mathrm{~d} f
$$

と表わせる。ここで $\mathrm{d} f$ は $\sigma_{\mathrm{B}}$ から $\sigma_{\mathrm{B}}+\mathrm{d} \sigma$ の間に離脱する転 位の割合である.式 (5)は，すべり系の分布や試料の応力 分布も含めて考慮した式と考兄てもよい. 図 8 に $\Delta_{\mathrm{H}}$ の概念 図を示す。いま $\Delta_{\mathrm{H}}$ を一定に保つようにして温度を変化させ ると, 式 $(5)$ から応力振幅 $\sigma_{0}$ が $\sigma_{\mathrm{B}}$ の一種の平均值 $\sqrt{\int \sigma_{\mathrm{B}}^{2} \mathrm{~d} f}$ と比例して変化することが分かる. あとで示す式 (7)から, $\sigma_{\mathrm{B}}$ の值が一析異なっていても $\sigma_{\mathrm{B}}$ の温度变化は $25 \%$ しか異 ならないことが分かる( ${ }^{(37)}$. 従って， $\sigma_{0}$ の温度変化を $\Delta_{\mathrm{H}}$ 一 定の下で測定すれば，その変化は標準的転位セグメントの $\sigma_{\mathrm{B}}$ の温度依存をかなりよい精度で表わしていることになる。

そこで $\sigma_{\mathrm{B}}$ の温度依存を考光る.離脱する転位セグメント の割合 $f$ の時間変化率は

$$
\frac{\mathrm{d} f}{\mathrm{~d} t}=(1-f) v \exp \left(-\frac{\Delta U}{k T}\right)
$$

で与えられる.ここでvは有効振動数因子で $10^{11} \mathrm{~Hz}$ 程度の 值をとる ${ }^{(38)}$. いま振動応力 $\sigma=\sigma_{0} \sin \omega t$ を与兄るとき， $\mathrm{d} f /$ $\mathrm{d} t$ が最大になるときの応力值を $\sigma_{\mathrm{B}}$ とすると， $\sigma_{\mathrm{B}}$ を与える 式が次のように求められる.

$$
\exp \left(-\frac{\Delta U}{k T}\right)=-\frac{\omega}{v} \frac{\sigma_{0}}{k T} \frac{\mathrm{d}(\Delta U)}{\mathrm{d} \sigma_{\mathrm{B}}}\left[1-\left(\frac{\sigma_{\mathrm{B}}}{\sigma_{0}}\right)^{2}\right]^{1 / 2}
$$

すなわち, 内部摩擦一定の条件に対応して $\sigma_{\mathrm{B}} / \sigma_{0}$ として一定

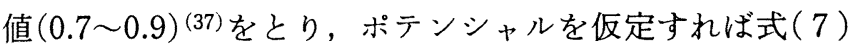
から $\sigma_{\mathrm{B}}(T)$ が求められる.これを $\sigma_{0}(T)$ と比較することで 相互作用ポテンシャル拉よびェネルギーが評価できる.

最初に，テストポテンシャルとして Cottrell 型ポテンシャ ルを試した(図 9). Cottrell ポテンシャルは式（1）に示した 関数で表わせるが, Cottrell は不純物の原子サイズ差の効果 を，線形弾性論に基ついてて導いた(6)(39)。実は，その他の原 因に基づく弾性率効果や電気的相互作用の場合でも，この関 数形はすべり方向の距離 $x$ に対して等しい(15)(18)，そこで 原因によらず線形弾性論に基づいているといらことで, Cottrell 型ポテンシャルと呼ぶことにする(29).

図10に実験値との比較を示した. Cottrell 型ポテンシャル

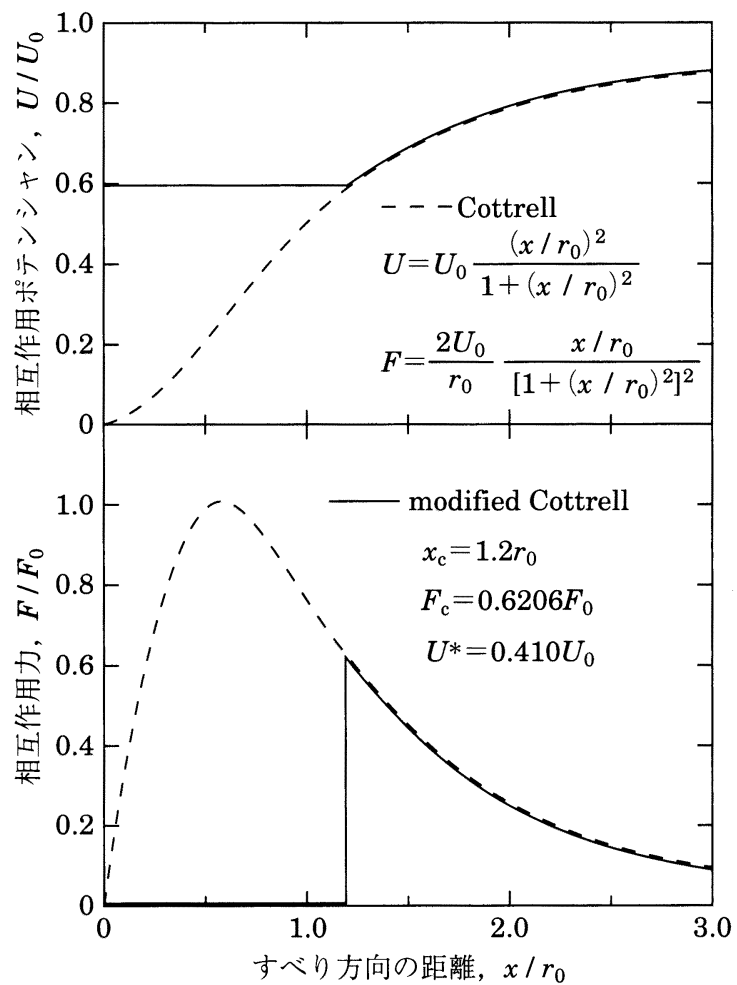

図 9 Cottrell ポテンシャルと転位芯の効果を考慮して 修正した modified Cottrell ポテンシャル.

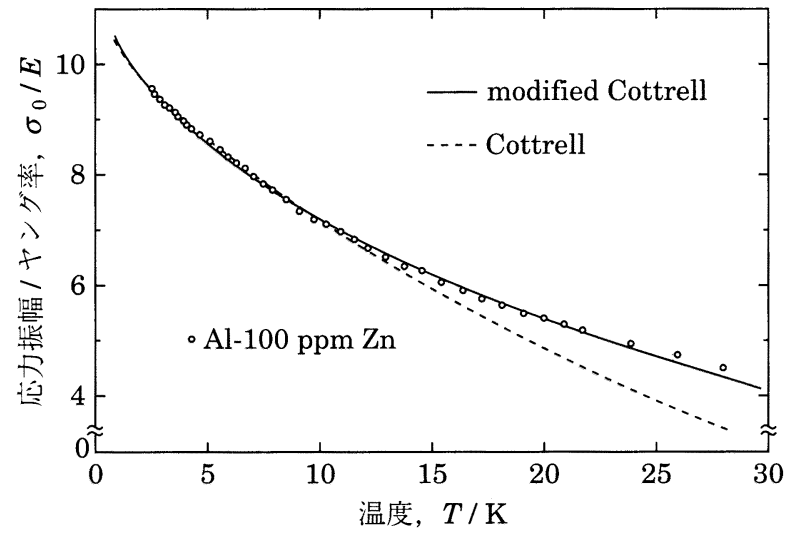

図10 一定量の $\Delta_{\mathrm{H}}$ に対する $\sigma_{0}$ の温度依存.

では測定範囲全域のよいフィットはできなかった．そこで以 下に述べるよらに，Cottrell 型ポテンシャルを修正した modified Cottrell (m-Cottrell) ポテンシャルを提案した。転位 中心から十分離れたところでは線形弾性論に従うはずだから， Cottrell 型ポテンシャルと同じ俵存性を考克, 転位中心付近 （転位芯）では格子の離散性のため歪に比べて応力が緩和して いると考光た。簡単のため, 図 9 に示すように, ある距離 $x_{\mathrm{c}}$ 以内ではポテンシャルがフラットになっているとした． $x_{\mathrm{c}}$ を変兄て実験值にフィットを試みたところ， $x_{\mathrm{c}}$ を $1.2 r_{0}$ より 大きくとればよいフィットが得られることが分かった(図10， 
11). $x_{\mathrm{c}}$ として例えば, $2.0 r_{0}, 4.0 r_{0}$ といら值を選んでもフィ ットの程度打よび相互作用ェネルギーは汪とんど変わらない が, その場合 Cottrell 型ポテンシャルのパラメーター $U_{0}$ と して非常に大きな值 $(\sim 1 \mathrm{eV})$ を仮定する必要があり, 現実 的でない. 従って， $x_{\mathrm{c}}$ として $1.2 r_{0}$ 程度が適当であると判断

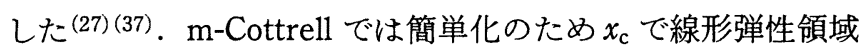
と転位芯領域をはっきり分けたが，図12に示すようにある幅 で遷移すると考えるのがより現実的であろう．そのような補 正の必要性にもかかわらず, 転位芯で線形弾性論が成り立た ず応力が大きく緩和していることが実験的に確認できたと考 えている. m-Cottrell を用いてそれぞれの溶質原子と転位の 相互作用エネルギーが $0.11 \mathrm{eV}(\mathrm{Zn}), 0.135 \mathrm{eV}(\mathrm{Ag}), 0.19$ $\mathrm{eV}(\mathrm{Mg}), 0.195 \mathrm{eV}(\mathrm{Cu})$ と求めることができた. 得られた相 互作用エネルギーは主に刃状成分を持つ転位に対応すると考 えられる (40)(41)ＦCC 金属ではらせん転位の場合でも，部

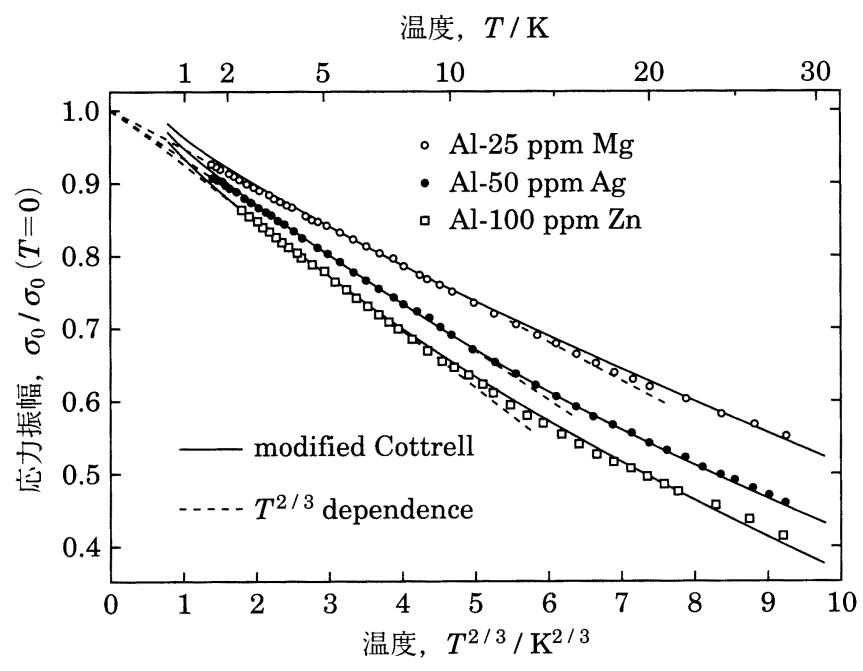

図11 修正した Cottrell ポテンシャルによるフィット. $\mathrm{Cu}$ の結果は $\mathrm{Mg}$ の結果と重なるため示していな い.これから相互作用エネルギーが $\mathrm{Cu}, \mathrm{Mg}, \mathrm{Ag}$, Zn 原子に対してそれぞれ $0.195 \mathrm{eV}, 0.19 \mathrm{eV}$, $0.135 \mathrm{eV}, 0.11 \mathrm{eV}$ と決定された.

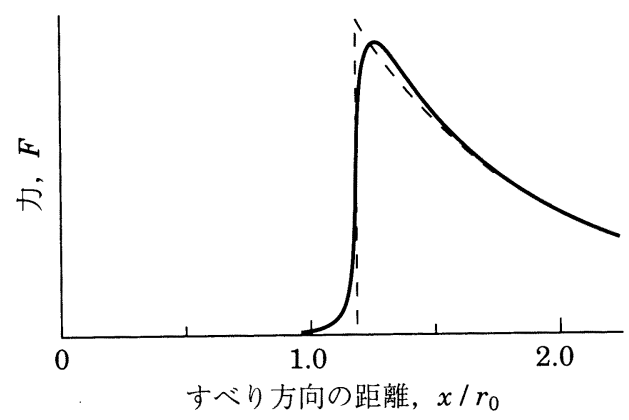

図12 modified Cottrell の相互作用力(破線) と期待さ れる実際の相互作用力(実線).
分転位に拡張することで刃状成分を持つ。

\section{4. 応用の可能性}

基本的相互作用すなわち 1 個の溶質原子と転位の相互作 用ポテンシャル特よび相互作用エネルギーが得られた。図13 に示すように，いろいろな現象および機構に対して応用の可 能性が考えられる(27)(32). ここではそのなかで基本的相互作 用の原因と固溶体強度の問題について考えてみる。

\section{（1）基本的相互作用の原因}

この問題は電子論に基づく第一原理計算研究の最近の急激 な進歩を考えると，より詳細な解明が期待できるテーマとい える.1950年代から60年代初めにかけて基本的相互作用 の機構に関する理論的アイデアがいくつも提案された。 Cottrell は原子のサイズ差による歪と刃状転位の応力場の相 互作用に基づく“サイズ効果”（Cottrell 効果とも呼ばれて いる)を考孚た(6)(39). また Fleischer 他は異種原子は母体と 異なる “弾性率”を持つため転位の応力場と相互作用すると 考えた(弾性率効果もしくは剛性率効果) (42)-(44). Cottrell, Hunter, Nabarro は金属中の刃状転位の昰場下での厷導電子 の不均一分布 (電気双極子) と異種原子の持つ電荷が相互作用 するとして“電気的相互作用”を提案した ${ }^{(45)}$. Suzuki は積 層欠陷を有する部分転位対に打梳る “化学的相互作用” (鈴木効果とも呼ばれている)を提案した ${ }^{(46)}$. 現在，一般的
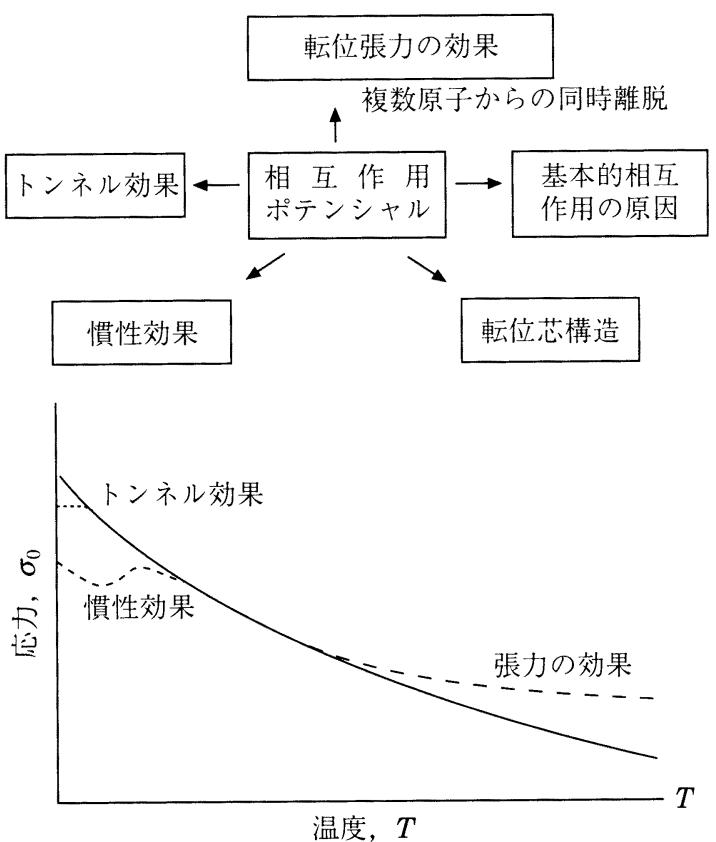

図13 内部摩擦 $\Delta_{\mathrm{H}}$ 一定での測定において基本的相互作 用から期待される応力振幅の温度依存之様々の 要因によるずれ。基本的相互作用の情報からの 応用例も示寸。 
表 $1 \mathrm{Al}$ 中の不純物原子と転位の相互作用に関する実験結果.

\begin{tabular}{|c|c|c|c|c|}
\hline 溶質原子 & $\begin{array}{l}\text { (1)隆伏応力の } \\
\text { 消失 }(\mathrm{eV})\end{array}$ & $\begin{array}{l}\text { (2)変形応力比 } \\
(78 \mathrm{~K})\end{array}$ & $\begin{array}{l}\text { (3)ADIF から得た相互作 } \\
\text { 用エネルキ(eV) }\end{array}$ & $\begin{array}{l}\text { (4)ADIF が現永机始める } \\
\text { 応力比 }(4.2 \mathrm{~K})\end{array}$ \\
\hline $\mathrm{Cu}$ & $\approx 0.3$ & 1.00 & 0.195 & 1.0 \\
\hline $\mathrm{Mg}$ & $0.2-0.27$ & 0.37 & 0.19 & 0.6 \\
\hline $\mathrm{Ge}$ & 0.17 & 0.64 & - & - \\
\hline $\mathrm{Ag}$ & - & 0.15 & 0.135 & 0.2 \\
\hline $\mathrm{Zn}$ & $0.08-0.11$ & 0.071 & 0.11 & 0.07 \\
\hline
\end{tabular}

な見方として，金属ではサイズ効果や弾性率効果などの弾性 的相互作用が最も重要と考光られているが, 必ずしもその根 拠はあまり明確ではない。

表 1 亿 $\mathrm{Al}$ 中の不純物原子と転位の相互作用の強さと関す る実験結果を示す．3 章で示した我々の結果の他に，(1)塑性 降伏現象が高温で消失する温度から推定された相互作用エネ ルギー(47)，(2) Dorn らによる $78 \mathrm{~K}$ での同濃度の希薄合金に 対する塑性変形応力比 ${ }^{(48)}$ を示す. 我々の結果のうち，(3) ADIF の温度依存から決定した相互作用エネルギーの值が(1) とょく一致しているのが分かる. 一方, (4) $4.2 \mathrm{~K}$ での ADIF の出現応力値から評価した同濃度合金のピン止め強度比が(2) とよく一致しているのが分かる.ここで強調したい点は, 例 えば相互作用エネルギーが大きい $\mathrm{Cu}$ 原子と小さい $\mathrm{Zn}$ 原子 のエネルギー比が 2 程度なのに対して, 塑性強度や ADIF の出現応力值ではその比が10以上になっていることである. ADIF の出現応力は, 相互作用エネルギーの大きさの他に, 転位線上の不純物濃度に注ぼ比例する. そして(3), (4)の結果 から相互作用の強い原子ほど転位線上に上り多く偏析してい ることが分かる. 従って，(2)の降伏応力比にも転位線上への 不純物原子の偏析が反映されているものと思われる. Cu 結 晶などの場合にも塑性強度比は溶質原子によって10倍も異 なることが報告されている(49)。このことは固溶体強度の律 速機構にも関わってくるので, 次節の固溶体強度の問題のと ころでまた触れたい。

基本的相互作用の問題として注目すべき点は, $\mathrm{Ag}$ 不純物 原子の効果である. Dorn らによっても指摘されていたが, 我々の結果からもサイズ効果が注注 0 と考光られる $\mathrm{Ag}$ 原子 が $\mathrm{Zn}$ 原子を上回る相互作用を持つことが明らかになった。

Dornらの結果がきっかけとなって, 最初に, 電気的相互 作用を議論したのは, Cottrell 達であるが, 彼等の計算結果 によると，そのエネルギーは $W_{\mathrm{e}}=-4 / 15 \delta Z \xi_{0} \Delta\left(r_{\mathrm{i}}\right)$ で与兄 られる(45). ここで, $\delta Z$ は溶質と溶媒原子の原子価の差, $\xi_{0}$ Fermi エネルギー, $\Delta\left(r_{\mathrm{i}}\right)$ 体積歪である. 彼らによると, $\mathrm{Al}$ の場合, 実効的な $\delta Z$ はスクリーニングのため約 0.04 倍小さ くなり, 原子価の差が 1 の場合 $0.02 \mathrm{eV}$ の寄与と計算され るが, これはサイズ効果に比べ一桁小さい，その後, Sugiyama は電気的相互作用を再検討し， $\delta Z$ としてほぼ原

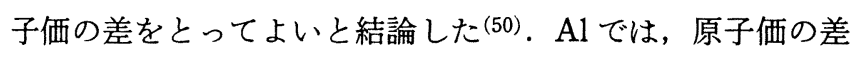

表 $2 \mathrm{Al}$ 中のサイズ効果と電気的相互作用(仮定値).

\begin{tabular}{ccclc}
\hline \hline 溶質原子 & $\eta$ & $W_{\mathrm{s}}(\mathrm{eV})$ & $W_{\mathrm{e}}(\mathrm{eV})$ & $W_{\mathrm{s}}+W_{\mathrm{e}}(\mathrm{eV})$ \\
\hline $\mathrm{Mg}$ & +0.255 & 0.256 & -0.0675 & 0.189 \\
$\mathrm{Cu}$ & -0.366 & 0.187 & +0.135 & 0.322 \\
$\mathrm{Zn}$ & -0.048 & 0.038 & +0.0675 & 0.106 \\
$\mathrm{Ag}$ & 0 & 0 & +0.135 & 0.135 \\
\hline
\end{tabular}

が 1 の場合 $0.46 \mathrm{eV}$ となり, サイズ効果と同程度となる. 上記の議論は線形弾性論に基づいた計算であり, 実際の相互 作用エネルギーはこれらの值より小さくなることが期待され る.

最近, Vörös と Kovácsは nonlocal elasticity 括よび quasi-continuum の考光を適用して転位芯に淤ける発散の問題を 回避し, 刃状転位に対してサイズ効果の式 $W_{\mathrm{s}}=0.211 \mu b^{3} \eta$ $(1+\eta)$ を示した ${ }^{(51)}$. ここで, $\mu$ : 剛性率, $b:$ Burgersでク トル, $\eta=3 / a \mathrm{~d} a / \mathrm{d} c$ ( $a$ 格子定数, $c$ 溶質濃度 $)$ である. その 結果を $\mathrm{Al}$ に適用した値を表 2 亿示す，それによると， Mg， $\mathrm{Cu}, \mathrm{Zn}, \mathrm{Ag}$ の順にサイズ効果が小さくなる. いま, 実験で 得た, Ag 原子との相互作用がすべて電気的相互作用による と仮定してみる.すると， 1 価の差に対して $0.0675 \mathrm{eV}$ が割 り当てられる.これを, 他の溶質原子にも考慮すると, 表 2 の 5 列目の値を得る. 結果は実験値をよく説明する. $0.0675 \mathrm{eV}$ という值は, Cottrell 達の $0.02 \mathrm{eV}$ に比べると大 きく, Sugiyama の $0.46 \mathrm{eV}$ に比べると小さい. 電気的相互 作用にも転位芯の影響を考慮すれば, 理論値は半分程度にな ると予想される. その場合でも Cottrellらの結果は過小評 価, Sugiyama の結果は過大評価していると結論される.

$\mathrm{Al}$ の場合, 弾性率効果は $\mathrm{Al}$ 自体の弾性率が小さいためせ いぜい $0.04 \mathrm{eV}$ 以下と評価される. そのうえ $\mathrm{Mg}$ 以外の溶 質原子で斥力相互作用となるので偏析の事実と合わない，ま た $\mathrm{A} 1$ 中の転位の部分転位への桩張はせいぜい数 $\AA$ 程度と小 さいので化学的相互作用は小さいと考兄られる.

\section{(2) 固溶体強度の問題}

固溶体強度を理解するらえで不純物原子障害に付随するパ ラメーターの設定には注意を要する。パラメーターの取り方 で要素過程がまるで違うものになるからである，例えば， 1 


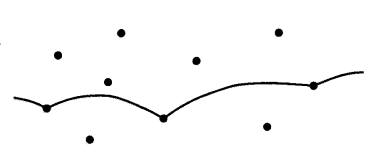

(a) Friedl-Fleischer 領域

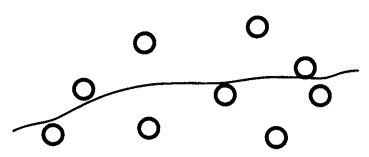

(b) Mott-Labusch 領域
図141本の転位の運動に括ける 2 つの要素過程.

本の転位がどのように不純物原子障害のもとで運動するかに ついては大きく分けて2つの要素過程が提案されてい る(19)(21) (図14). 1つは Friedel が最初に考えた点障害モデ ルに基づく過程でランダムに平面分布する点障害中を転位が “1 個ごとの点障害との離脱”を要素過程として, 離合を繰 り返しながら進むといら考えである(52)(53) (Friedel-Fleischer 領域)。いま 1 つは Labuschによって明快に取り扱われた場 合で, 転位の張力の効果のため離脱過程において “複数の原 子と同時に相互作用する”ことを前提としたモデルであ

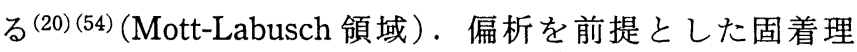
論(55)-(57) は複数の原子との相互作用を基礎に置く点で,

Mott-Labusch 領域に含まれる.2つの過程は相互作用の強 さや不純物原子濃度により遷移する．強い相互作用，低濃度 の場合は Friedel-Fleischer 領域, 弱い相互作用, 高濃度の 場合は Mott-Labusch 領域といらょうに.

多くの転位が増殖しながら運動するとき，すなわち塑性現 象そのものの律速過程がどの機構によるのか, はっきり結論 できない状況が続いている．転位の移動が律速するという考 えが “摩擦機構”(15)(58), 転位の増殖過程が律速するという のが “固着機構”(55)-(57) と呼ばれている.

1 本の転位の運動の問題に関してまず考えよう。塑性に拉 いて固溶体強度が現われるような合金では溶質原子濃度が $0.1 \%$ 超えて扣り，2 章でも示したように，実際の要素過 程は 1 個の原子との相互作用 (Friedel-Fleischer 領域)では ないと考えられる. 事実, 塑性変形の降伏応力の温度依存か ら推定される相互作用エネルギーは一般に $0.5 \mathrm{eV}$ 以上の大 さな値である(23)-(25)。これは多数の原子と相互作用する過 程(Mott-Labusch 領域) と考旮れば説明できる(23). ADIF の 測定では両領域での遷移が観測できる. 図15に我々の実験結 果例を示す. 非常に高純度の帯精製 $\mathrm{Al}(\sim 1 \mathrm{ppm})$ では 1 個 の原子との相互作用(基本的相互作用)を反映した温度依存が 低応力領域までずっと成り立つが，Al-25 ppm Mg では途中 から多原子相互作用の過程に遷移している.この領域での温 度依存は $1 / T$ に比例することが Granato らによって予測さ れているが(28)(36), 我々の結果はそうなっている。

次に強度を決める律速過程の問題を考えよう. 増殖過程を 伴わない ADIF の実験だけからは直接的な証拠を示すこと はできない，しかしながら，基本的相互作用の議論のところ で述べたように， $\mathrm{Al}$ 結晶の場合 $\mathrm{Zn}$ と $\mathrm{Cu}$ で基本的相互作用 のエネルギーが 2 倍しか異ならないのに, Dorn らの塑性実

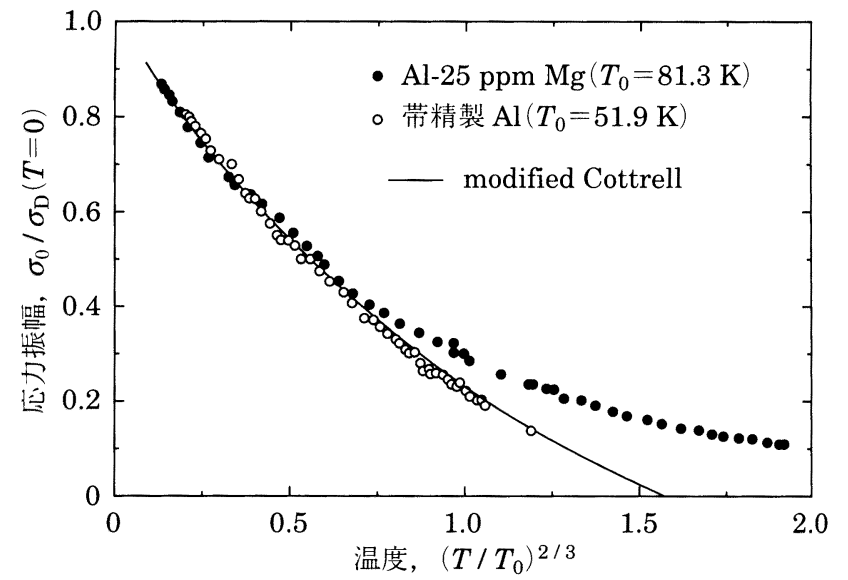

図15 Al-25 ppm Mg と帯精製 $\mathrm{Al}(\sim 1 \mathrm{ppm})$ 結晶の $\Delta_{\mathrm{H}}$ 一定での応力振幅の温度依存.

験の結果では変形応力の比が 10 倍以上も異なる(表 1).これ は偏析を考慮して初めて説明できる。すなわち転位は偏析の ある領域で運動を起こす過程によって律速されていると考兄 られる。我々の取り上げた $\mathrm{Al}$ 希薄合金の系では固溶体強度 の律速機構として固着機構が摩擦機構より有力だと考えられ る.

\section{5. おわりに}

転位と不純物原子の基本的相互作用を調べるのに，ADIF が真に有効であることが分かった．相互作用ポテンシャルが 実験的に決定できた。そこには転位芯の効果も見い出され た. 基本的相互作用を理論的に考えるための問題点がかなり 明らかにできたと思劣る.1つは電気的相互作用が無視でき ないこと、また線形弾性論では正確な相互作用エネルギーを 予測できないこと. 転位芯付近の正確な原子位置を取り入れ た第一原理的電子論に基づいた相互作用エネルギーの計算が 望まれる. そのさい, 我々の方法で実験的に求めた相互作用 エネルギーのデータが参考になる. 固溶体強度の問題では 1 本の転位の運動の要素過程の変遷が ADIF 測定によって明 確に示すことができた(図15). 塑性に括ける固溶体強度現 象は多数の原子と転位が同時に相互作用する過程 (MottLabusch 領域) と考えてょいと結論される. さらに実際の強 度には偏析の効果が現われていることが分かった.このこと から，少なくとも我々の調べた $\mathrm{Al}$ 結晶においては固溶体強 度の律速過程は増殖過程であって移動過程ではないと言えそ らだ.

基本的相互作用のポテンシャルの情報を用いて，さらにほ かにもトンネル効果の問題(32)(59), 慣性効果の問題(60)(61)な ど今回は取り上げる余裕がなかった興味深いテーマを探るこ とができる(図13参照). 
最後に, 我々の研究を紹介する機会を与えてくださった 小岩昌宏京都大学教授叔よび沼倉 宏京都大学助教授にこの 場を借りて謝意を表したい。

この研究の一部は, 科研費 (課題番号10120224)の補助の もとに行われた。

\section{文献}

(1) C. S. Smith: Solid State Science, eds. D. L. Weaire and C. G. Windsor, Adams Hilger, Bristol, (1987), p. 11.

(2) T. H. Courtney: Mechanical Behaviors of Materials, McGrawHill, New York, (1990).

(3) G. I. Taylor: Proc. R. Soc., A145(1934), 362.

(4) E. Orowan: Z. Phys., 89(1934), 634.

(5) M. Polanyi: Z. Phys., 89(1934), 660.

(6) A. H. Cottrell: Strength of Solids, The Phys. Soc., London, (1948), p. 30.

(7) Dislocations and Mechanical Properties of Crystals, eds. J. C. Fisher et al., John Wiley \& Sons, New York, (1957).

(8) Dislocations Dynamics, eds. A. R. Rosenfield et al., McGrawHill, New York, (1968).

（9）物理学論文選集 211 , 塑性 N, 竹内 伸, 蔵元英一編, 日本物 理学会, (1980).

(10) Dislocations in Solids, eds. H. Suzuki et al., Univ. Tokyo, Tokyo, (1985).

(11) 鈴木 平, 吉永日出男, 竹内 伸：転位のダイナミックスと 塑性, 裳華房, (1985).

（12）“特集固体中の転位”，日本金属学会会報， 23(1984)，445.

（13）鈴木敬愛：日本物理学会誌, 53(1998), 833.

(14) H. Suzuki: Dislocations in Solids Vol. 4, ed. F. R. N. Nabarro, North-Holland, Amsterdam, (1979), p. 191.

(15) P. Haasen: Dislocations in Solids Vol. 4, North-Holland, (1979), p. 155.

(16) P. Haasen: Phys. Metall., eds. W. Cahn and P. Haasen, Elsevier, (1983), p. 1342.

（17）第 6 回格子欠陥フォーラム概要集「転位-現状と将来の展望」, 格子欠陥フォーラム事務局, (1996).

（18）鈴木秀次：転位論入門，アグネ，(1967), p. 282.

(19) F. R. N. Nabarro: Physics of Metals, 2. Defects, ed. P. B. Hirsch, Cambridge, London, (1975). : 堂山, 二宮, 竹内訳 : 金属の 物理, 格子欠陥, 丸善, (1976), p. 129.

(20) R. Labusch: Phys. Stat. Solidi, 41(1970), 659.

(21) F. R. N. Nabarro: Philos. Mag., 35(1977), 613.

(22) R. B. Schwarz and R. Labusch: J. Appl. Phys., 49(1978), 5174.

(23) R. J. Arsenault and S. Li: Metall. Trans., 20A(1989), 1429.

(24) H. Neuhauser and C. Schwink: Mater. Sci. Tech. Vol. 6, ed. H. Mughrabi, VCH Weinheim, (1993), p. 191.

（25）鈴木秀次(監修)：金属の強さ，アグネ，(1972）.

(26) R. W. Balluffi and A. V. Granato: Dislocations in Solids Vol. 4, ed. F. R. N. Nabarro, North-Holland, Amsterdam, (1979), p. 1.

(27) T. Kosugi and T. Kino: Mater. Sci. Eng., A164(1993), 316.
(28) L. J. Teutonico, A. V. Granato and K. Lücke: J. Appl. Phys., 35 (1964), 220.

(29) L. J. Teutonico, K. Lücke, F. W. Heuser and A. V. Granato: J. Acoust. Soc. Ame., 45(1969), 1402.

(30) T. Kosugi: Jpn. J. Appl. Phys., 33(1994), 2862.

（31）比企能夫：弾性·非弾性, 共立出版, (1972), p. 125.

（32）小杉俊男：金属, 68(1998), 983.

(33) R. B. Schwarz and A. V. Granato: Phys. Rev. Lett., 34(1975), 1174.

(34) R. B. Schwarz, R. D. Isaac and A. V. Granato: Phys. Rev. Lett., 38(1977), 554.

(35) A. V. Granato and K. Lücke: J. Appl. Phys., 27 (1956), 583.

(36) A. V. Granato and K. Lücke: J. Appl. Phys., 52 (1981), 7136.

(37) T. Kosugi and T. Kino: J. Phys. Soc. Jpn., 56 (1987), 999.

(38) A. V. Granato, K. Lücke, J. Schlipf and L. J. Teutonico: J. Appl. Phys., 35 (1964), 2732.

(39) A. H. Cottrell: Dislocations and Plastic flow in Crystals, Oxford, London, (1953), p. 56.

(40) T. Kosugi and T. Kino: Jpn. J. Appl. Phys., 26(1987), 26-3, p. 881.

(41) T. Kosugi and T. Kino: Proc. Int. Conf. Internal Friction and Ultrasonic Attenuation in Solids, ed. T. S. Ke, Pergamon, New York, (1990), p. 33.

(42) C. Crussard: Metaux et Corrosion, 25(1950), 203.

(43) J. Friedel: Dislocations, Pergamon, Oxford, (1964), p. 360.

(44) R. L. Fleischer: Acta Metall., 9(1961), 996.

(45) A. H. Cottrell, S. C. Hunter and F. R. N. Nabarro: Philos. Mag., 44(1953), 1064.

(46) H. Suzuki: Sci. Rep. Res. Inst. Tohoku Univ., A6 (1952), 309.

(47) J. Friedel: Dislocations, Pergamon, Oxford, (1964), p. 351.

(48) J. E. Dorn, P. Pietrokowsky and T. E. Tiets: Trans. Metall. Soc. AIME, 188(1950), 933.

(49) R. L. Fleischer: Acta Metall., 11(1963), 203.

(50) A. Sugiyama: J. Phys. Soc. Jpn., 21(1966), 1873.

(51) G. Vörös and I. Kovács: Philos. Mag., A72 (1995), 949.

(52) J. Friedel: Les Dislocation, Gauthier-Villars, Paris, (1956), p. 205.

(53) R. L. Fleischer and W. R. Hibbard, Jr: The Relation between the Structure and Mechanical Properties of Metals, Vol 1, HMSO, London, (1963), p. 261.

(54) N. F. Mott: Imperfections in Nearly Perfect Crystals, JohnWiley and Sons, New York, (1952), p. 173.

(55) H. Suzuki: Strength of metals and Alloys (ICSMA-5), eds. P. Haasen et al., Pergamon, (1980), p. 1595.

(56) U. F. Kocks: Metall. Trans., 16A(1985), 2109.

(57) H. Suzuki: Strength of Metals and Alloys (ICSMA-7), eds. H. J. McQueen et al., Pergamon, (1986), p. 1727.

(58) T. Suzuki: Jpn. J. Appl. Phys., 20(1981), 449.

(59) T. Kosugi, D. McKay and A. V. Granato: J. de Physique N, 6(1996), 863.

(60) T. Kosugi: Strength of Materials (ICSMA-10), eds. H. Oikawa et al., JIM, (1994), p. 133.

(61) T. Kosugi, I. Kubota and I. Nakamichi: Proc. Int. Conf. Microstructures and Functions of Materials, eds. N. Igata et al., ICMFM96, Tokyo, (1996), p. 109. 